\title{
REINFORCEMENT OF PANCASILA AS A PHILOSOPHY OF REGULATION-MAKING
}

\author{
Lita Tyesta ALW \\ Faculty of Law, Universitas Diponegoro \\ litatyestaaddylistya@lecturer.undip.ac.id
}

\begin{abstract}
The purpose of law is to implement the ideals of order and justice into the interpersonal space of life that is society. Therefore, every legal regulation must abide and be based on norms that exist in society which envisages the modern ordered and just society. The law should be prospective, understandable, clear, fixed and certain. In Indonesia, Pancasila is a set of five principles by which the whole systems of government, law, and social life should be adopted by the nation. However, the current political climate has changed the political reception towards reinforcing Pancasila as the basic philosophy of regulation-making. This conceptual article discussed about how the process of regulation-making should be based on Pancasila as grundnorm, or basic norms of the nation's life. This article concluded that the elaboration of the grundnorm in the formation of laws and regulations by taking into account the principles of the formation of laws and regulations as well as the principles of material content along with the guidelines and techniques for their formation, so that the formation of laws and regulations fulfills the rules in substance (materially) and formally.
\end{abstract}

Keywords: Pancasila; Grundnorm; Regulation-Making

\section{Introduction}

Law and regulations in a state of law are as a tool so that the authorities and citizens are restricted and act consistently based on the law. Therefore, the law must be applied forward (prospective), understood by the public, clear, fixed and certain, and applied to whoever the law is intended. Not fulfilling these characteristics, the law is considered inadequate ${ }^{1}$.

The definition above is 'formal' definition although other broader definitions can be made, namely by including basic rights, democracy and/or criteria about justice and rights. The formal definition is put forward because it most often represents other definitions that exist as a baseline.

One function of the legal rules is to limit the actions of the authorities in two ways: (i) obeythe existing legal rules, and (ii) apply legal limits on the powers of lawmakers. Another function of the legal rules is to maintain order, to guide the behavior and governance among citizens ${ }^{2}$. In carrying out this function, law is a regulator of social behavior.

\footnotetext{
1 Brian Z Tamanaha, "A Concise Guide to The Rule of Law," in Relocating The Rule of Law (Oxford: Hart Publishing, 2009), 5.

2 Ibid.
} 
At the most general level, as stated by Friedman, the legal system has a function to spread and maintain the correct allocation of values according to the society ${ }^{3}$ (the function of the legal system is to distribute and maintain an allocation of values that society feels to be right). Further explained that the function of the legal system is ${ }^{4}$ : (1) Justice, where welfare and respect are allocated among citizens; (2) Settlement of disputes, provide institutions and places that citizens can go to to resolve conflicts and resolve their disputes; (3) Social control, enforcement of rules regarding correct behavior; and (4) Create the norms, act as an instrument for making ordered changes, namely social engineering.

Norms or principles in social life are needed to fulfill existing legal functions. Norms or principles are the institutionalization of good and bad values in the form of rules that contain permissions, advice, or orders 5 .

The purpose of the law principles or legal norms is aimed at the ideals of interpersonal peace of life (het recht wil de vrede). Therefore, it is often said that law enforcement works "to preserve peace". In peace or a state of peace there is always "order en rust". "Order" concerns order and security, while "rust" deals with serenity and composure. "Order" is related to the outward dimension, while "rust" concerns the "inner" dimension. The state of peace which is the ultimate goal of legal norms lies in the balance between "rust" and "order", namely between the outward and inner dimensions that produce a balance between order and peace, between security and composure ${ }^{6}$. The purpose of peaceful living in togetherness is usually also associated with the formulation of the law principles, namely to realize certainty, equity and utility ${ }^{7}$.

How law and regulations was formed? So that the norms or rules described above become something inherent both in the administration of the state and social life. Thus the purpose of peaceful living together can be realized real.

Francesco Parisi \& Vincy Fon (2009), in their book The Economics of Lawmaking, identified the formation of legislation, i.e.: (1) the formation of law through legislation: codified law (lawmaking through legislation: codified law); (2) formation of law through decision court: the law of the court's decision: (lawmaking through adjudication: judge-made law); (3) formation

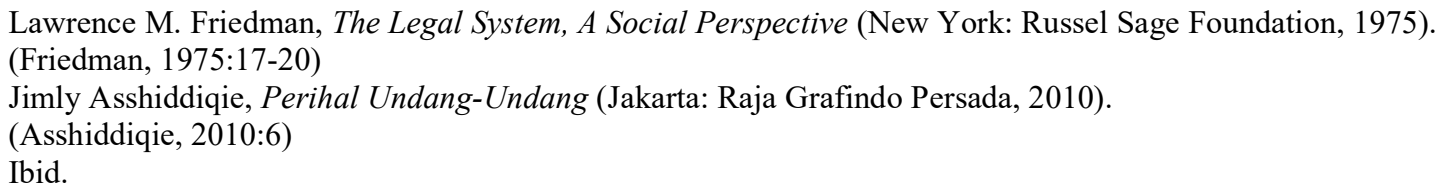


of law through practice: customary law (lawmaking through practice: customary law); and (4) formation by agreement: law of agreement (lawmaking through agreement: treaty law) ${ }^{8}$.

How should law be formed? Who should shape it? These fundamental questions are raised by many legal experts. Although it is very important, because it involves both theoretical and practical importance, a systematic discussion of legal sources has not been satisfactorily discussed in the literatures 9 .

\section{Discussion}

\subsection{Pancasila as Grundnorm}

A legal order is a unitary "objective law" that is when seen from the outside does not depend on other legal procedures, whereas when viewed from the inside it determines a specific and specific legal formation ${ }^{10}$. Hans Kelsen has argued about the unity of order in the process of forming a hierarchical and dynamic law. According to Hans Kelsen,the formation of law by an authorized institution to establish law depends on the establishment of a higher law, so that all legal orders are returned to something rooted in a groundnorm ${ }^{11}$.

Grundnorm can be understood in two senses, namely groundnorm in the sense of Hans Kelsen and groundnorm in another sense, namely in the teaching of the origin of the source of law ${ }^{12}$. First, grundnorm in the sense of Hans Kelsen can be classified into four indicators, ( Compare with Jazim Hamidi's opinion on the nine characteristics contained in the understanding of Hans Kelsen's grundnorm) i.e. ${ }^{13}$ : (1) Grundnorm is something abstract, assumed, not written, and has universal applicability; (2) He does not shift (determined), but vorausgesetzt (assumed) the existence of human reason; (3) It does not enter into a positive legal order, it is outside but becomes the highest foundation of behavior for a positive legal order. He is metajuristic in nature.

Second, grundnorm in another sense, namely in relation to the teaching "origin of the source of law". In this context, grundnorm is the source of the highest and last applicable law (source of the sources). It gives a cognizance why the law must be implemented. Although

\footnotetext{
(Asshiddiqie, 2010:xiii)

Francesco and Vincy Fon Parisi, The Economics of Lawmaking (Oxford: Oxford University Press, 2008).

Stammler, Theorie Der Rechtwissenschaft (Halle: Buchhandlung des Waisenhauses, 1911).

Roeslan Saleh, Penjabaran Pancasila Dan UUD 45 Dalam Perundang-Undangan (Jakarta: Aksara Baru, 1979).

12 Jazim Hamidi, "Legal Status of the Proclamation Manuscript of August 17, 1945 in the Indonesian State Administration System," Journal Constitution 3, no. 1 (2006): 103.

13 Jazim Hamidi, Revolusi Hukum Indonesia: Makna, Kedudukan, Dan Implikasi Hukum Naskah Proklamasi 17 Agustus 1945 Dalam Sistem Ketatanegaraan RI (Jakarta: Konstitusi Press, 2006).
} 
disobedience to Pancasila has no sanction. It was accepted by the community axiomatically. The word norm in grundnorm terminology refers to a norm that is general in nature, such as religious norms, norms of decency, norms of courtesy, and other norms.

Pancasila can be classified in full as grundnorm both referring to the first definition of grundnorm, and the second understanding of grundnorm. Pancasila fulfills four indicators as in the first understanding of grundnorm, as well as in the second sense, which places grundnorm as the peak ofnorms that exist in the state, below it are followed by norms that are lower in level. Through superior relationships, the highest norms then will be concreted in the lower norms to the most concrete norms, or also called the "konkritzierung" process ${ }^{14}$.

Judging from the position of the Pancasila in the Preamble to the Republic of Indonesia 1945 Constitusion and also taking into account the formulation of the function in the opening, Pancasila is a grundnorm not only of legal norms, but of all the norms of Indonesian life. Thus it can be phrased Pancasila and Indonesian law and order as follows ${ }^{15}$ : (1) Pancasila is a grundnorm (basic norm), for the life of the nation, society and state of Indonesia. Pancasila is broader than what was stated by Hans Kelsen who discusses grundnorm only as a basic norm of an orderly law. Therefore, if people commonly express the jurisdiction of juridists in the diversity of legal norms, with Pancasila we can construct the unity in the diversity of norms; (2) Pancasila is not only the basic norms of Indonesian law and order, but also the basic norms of other norms such as moral norms, decency, ethics and so on; (3) Pancasila requires that Indonesian law and order also be in line with moral norms, decency, ethics and so on, because in the Pancasila also contained these norms.

Pancasila is the source of material law from Indonesian law, so that legal thoughts and the draft of regulations that are not in accordance with Pancasila may not be determined. This is where the Pancasila is located as the basis of Indonesian law and order, as a guide and direction for its development ${ }^{16}$.

Meanwhile, according to Hans Kelsen, the hierarchy of legal norms is grouped so that norm buildings consist of basic norms, general norms and concrete norms. Fundamental norms are contained in the constitution, general norms are found in laws, "statutes" or "legislative acts",

\footnotetext{
(Darmodihardjo, 2004:116)

(Saleh, 1979:44-45)

(Saleh, 1979:51)
} 
whereas concrete norms are found in court decisions (vonnis) and decisions of State administrative officials ${ }^{17}$.

So according to Hans Kelsen that legal norms are tiered and multi-layered in a hierarchy (arrangement), in a sense, a lower norm applies, sourced and based on higher norms, higher norms apply, sourced from even higher norms, and so on until they arrive at a norm that can no longer be traced further and is hypothetical, namely the basic norm (grundnorm) ${ }^{18}$.

Law always contains idealized legal norms (ideal norms) by a society towards the noble ideals of community and state life to be directed. Therefore, Law can be described as a mirror of the collective ideals of a society about noble and philosophical values which are to be realized in daily life through the implementation of the relevant laws in reality. So, the philosophical ideals contained in the law should reflect the philosophical ideals adopted by the people of the nation concerned itself. This means that the philosophical ideals contained in the law are not compatible with the philosophical ideals of the nation itself. Therefore, in the context of state life, Pancasila as a philosophy must be reflected in philosophical considerations contained in each law. Pancasila is the philosophical basis for all products of the Republic of Indonesia law based on the 1945 Constitution ${ }^{19}$.

Pancasila as a grundnorm becomes the spirit that underlies the rule of law in Indonesia. Pancasila is the pathway for every legislation that is made and passed. Every norm contained in the legislation must be in accordance with the 1945 Constitution which contains the values contained in Pancasila. Pancasila is the foundation for the material content of each applicable legislation.

\subsection{Pancasila as a Basic Value for Establishment of Legal Regulations}

Hans Nawiasky, as quoted by Maria Farida, as a student of Hans Kelsen, developed the theory of norm levels, Hans Nawiasky argued that besides norms were multi-layered and tiered, the legal norms of a country were also in groups, and the grouping of the country's legal norms consisted of four major groups, i.e.: (1) the group of fundamental norms of the state (staatsfundamentalnorm); (2) a group of basic rules of the state / basic rules of the state

\footnotetext{
(Kelsen, 1961:112)

(Kelsen, 1961:113)

(Asshiddiqie, 2010:117-118)
} 
(staatsgrundgesetz); (3) formal statutory groups (formell gesetz); and (4) group of implementing rules / autonomous rules (verordnung \& autonome satzung ${ }^{20}$.

In the Indonesian legal system, all statutory regulations of any kind must be based on and sourced from and may not conflict with the basic norms (staatsfundamentalnorm), namely Pancasila as an ideal value as well as an ideology of a country which is located as a framework that unites or becomes an estuary for various existing statutory regulations. While the basic value is the 1945 Constitution which is the basic law. As a basic law, the 1945 Constitution is the highest source of law in the order of legal norms in Indonesia, meaning that any type of legislation must be based and must not conflict with the 1945 Constitution.

In the hierarchy level, all the laws and regulations from the top level (1945 Constitution) to the lower level regulations must be in harmony with one another. To find out whether the existing regulations in Indonesia have been harmonious so far, it is necessary to conduct a study of the vertical and horizontal synchronization levels which are part of normative research. The activity is carried out through inventorying, describing, interpreting, and systematizing all positive laws that arestill valid in order to prepare efforts to find and offer a legal solution to the concrete legal problems that occur in the community ${ }^{21}$.

Article 1 paragraph (3) of the 1945 Constitution states that Indonesia is a state law, this contains the consequence that Indonesia adheres to a system of rule of law. This means that all actions of the government and the community must be based on norms/legal norms/laws and regulations, therefore a legal basis or source of legitimacy that can be used as a guideline in the making of norms/rules of positive law.

In modern law countries, the formation of statutory regulations, of any kind, is the most important process. The importance of this role is because it helps legislation to create abstract behavioral models that can later be expected to be used to solve concrete social problems ${ }^{22}$.

In the laws and regulations contained the existence of legal principles, where the legal principle according to Paton as quoted by Satjipto Rahardjo in his book "Legal Studies" is an important and essential element of the rule of law. It is even mentioned as the "heart" of the rule of law, because that principle is the broadest basis for the birth of a rule of law. This means that

20 Maria Farida Indrati, Ilmu Perundang-Undangan Jenis, Fungsi Dan Materi Muatan (Yogyakarta: Kanisius, 2011).

21 Bernard Arief Sidharta, "Penelitian Hukum Normatif," in Metode Penelitian Hukum: Konstelasi Dan Refleksi (Jakarta: Yayasan Obor Indonesia, 2009), 142-149.

22 D.H.M. Meuwissen, Pengembanan Hukum, Ilmu Hukum, Teori Hukum, Dan Filsafat Hukum, ed. Bernard Arief Sidharta (Bandung: Refika Aditama, 2007). 
legal regulations can eventually be returned to these principles. Even Paton called it the "ratio legis", which would give birth to further regulations and would never be exhausted, it was precisely the means that made the law alive, growing and developing ${ }^{23}$. Thus the principle of law is the basis or direction in the formation of positive law, which forms the contents of the rule of law and without the principles of the law, the rule of law will lose its binding power ${ }^{24}$.

Ratio legis is an attempt to find the meaning of a regulation by looking at the higher regulations. Through withdrawal from a higher level, broader understanding will be found, more general in scope than before. Thus it can be said that without finding the legis ratio of a rule, it will be less able to understand the ethical directions of a rule. On the contrary, by finding the legis ratio, it will be possible to construct a further structure which is consistent with the existing regulations 25 .

Lon L. Fuller in one part of his book entitled Eight Ways To Fail To Make Law, mentions that there are eight things that are demanded from the law in relation to morality that can be used as a principle in forming legislation, namely (1) The Generality of Law; (2) Promulgation; (3) Retroactive of Laws; (4) The Clarity of Laws; (5) Contradiction in Laws; (6) Laws Requiring the Impossible;(7) Constancy of the Law Through Time; (8) Congruence between official Action and Declared Rule ${ }^{26}$.

Lon L Fuller's explanation above reminds us of things that need to be considered by the legislators, that in creating and maintaining legal rules, it is necessary to pay attention to the eight things mentioned above so that the regulations that are formed do not fail in its implementation. Therefore, in reviewing normatively every legal product formed, it is necessary to pay attention to the legality principle from Fuller to assess whether the various laws and regulations that are formed are in accordance with the principles conveyed by Lon Fuller.

Meanwhile, according to Maria Farida Indrati S, the principles of establishing legislation are guidelines or signs in the good formation of laws and regulations. ${ }^{27}$ I.C.Van der Vlies in Handboek Wetgeving discusses the principle of establishing legislation and refers to it as "beginselen van behoorlijke regelgeving" (the principles of establishing good legislation). The principle relates to norms that must be realized in government actions and which can be enforced

\footnotetext{
(Rahardjo, 1986: 85-86)

Ibid.

Ibid.

Lon L. Fuller, The Morality of Law, Revised Ed. (Virginia: Yale University, 1969).

(Indrati, 2011:252)
} 
by judges. For example the principle of equal treatment of citizens (gelijkheidsbeginsel). ${ }^{28}$ I.C. van der Vlies divides the principles in the formation of good state legislation into formal and material principles. ${ }^{29}$

Formal principles include: (1) the principle of clear objectives (beginsel van duidelijke doelstelling); (2) appropriate organs/institutions (beginsel van het juiste organ); (3) the principle of the need for regulation (het noodzakelijkheids beginsel); (4) principles can be implemented (hetbeginsel van uitvoerbaarheid); (5) the principle of consensus (het beginsel van consensus). Whereas the principle of material includes: (1) the principles of correct terminology and systematics (het beginsel van duidelijke terminology en duidelijke systematiek); (2) the principle of recognizable (het beginsel van de kenbaarheid), (3) the principle of equal treatment in law (het rechtsgelijkheids beginsel); (4) the principle of legal certainty (her rechtszekerheidsbeginsel); (5) the principle of implementing the law in accordance with individual circumstances (het beginsel van der individuele rechtsbedeling).

If there is an objective condition (existing) in which the norms or rules of law or legislation, both ius constitutum and ius operatum, do not obey the principle, then the law will not achieve justice, usefulness or certainty. Although according to Gustav Rabruch, the three legal objectives which are the "three basic values of the law" will always be in a state or potential spannungsverhanltis or will always be in tension with each other so that the three cannot be created simultaneously in accordance with the wishes of the community because there is always a purpose or the basic value is left behind if the objective or basic value that will be prioritized or prioritized ${ }^{30}$, but the objective condition (existing) must be improved by returning to its legal principles. This is done by submitting a judicial review to the MA or constitutional review. Article 5 of Law Number 12 Year 2011, the formation of laws and regulations must be based on the principle of the formation of good legislation, which includes: a. the principle of clarity of purpose, b. appropriate institution or forming organ, c. match between type and material content, $d$. can be implemented, e. usefulness and usability, f. clarity of the formula, and g. openness.Also in Article 6 paragraph (1) and (2) of Law Number 12 Year 2011, it is determined that the material contained in legislation contains the following principles: a. protection, b. humanity, c. nationality, d. kinship, e. archipelago, f. Bhineka Tunggal Ika, g. justice, h. common position in law and government, i. order and legal certainty, and / balance,

\footnotetext{
(Vlies, 2005:249)

(Vlies, 2005:251)

${ }^{30}$ (Rahardjo, 1986:18-21)
} 
harmony, and harmony, and other principles in accordance with the legal field of the relevant legislation, i. order and legal certainty, and / balance, harmony, and harmony, and other principles in accordance with the legal field of the relevant legislation.

\section{Conclusions}

The formation of various laws and regulations in Indonesia must refer to the basic values, namely the values of Pancasila, because Pancasila is the source of all sources of law in Indonesia, besides that it also originates in the 1945 Constitution as a basic law which is a derivative from Pancasila values. Therefore, in order to understand the basic values of Pancasila, it is necessary to have an elaboration in the context of establishing legislation. Whereas in the elaboration of the values in the formation of laws and regulations by taking into account the principles of the formation of laws and regulations as well as the principles of material content along with the guidelines and techniques for their formation, so that the formation of laws and regulations fulfills the rules in substance (materially) and formally.

\section{References}

Asshiddiqie, Jimly. Perihal Undang-Undang. Jakarta: Raja Grafindo Persada, 2010.

Darmodihardjo, Dardji and Sidharta. Penjabaran Nilai-Nilai Pancasila Dalam Sistem Hukum Indonesia. Jakarta: Raja Grafindo Persada, 2004.

Friedman, Lawrence M. The Legal System, A Social Perspective. New York: Russel Sage Foundation, 1975.

Fuller, Lon L. The Morality of Law. Revised Ed. Virginia: Yale University, 1969.

Hamidi, Jazim. "Legal Status of the Proclamation Manuscript of August 17, 1945 in the Indonesian State Administration System.” Journal Constitution 3, no. 1 (2006): 103.

—. Revolusi Hukum Indonesia: Makna, Kedudukan, Dan Implikasi Hukum Naskah Proklamasi 17 Agustus 1945 Dalam Sistem Ketatanegaraan RI. Jakarta: Konstitusi Press, 2006.

Indrati, Maria Farida. Ilmu Perundang-Undangan Jenis, Fungsi Dan Materi Muatan. Yogyakarta: Kanisius, 2011.

Kelsen, Hans. General Theory of Law and State. Cambridge: Harvard University Press, 1961.

Meuwissen, D.H.M. Pengembanan Hukum, Ilmu Hukum, Teori Hukum, Dan Filsafat Hukum. Edited by Bernard Arief Sidharta. Bandung: Refika Aditama, 2007. 
Parisi, Francesco and Vincy Fon. The Economics of Lawmaking. Oxford: Oxford University Press, 2008.

Rahardjo, Satjipto. Ilmu Hukum. Bandung: Alumni, 1986.

Saleh, Roeslan. Penjabaran Pancasila Dan UUD 45 Dalam Perundang-Undangan. Jakarta: Aksara Baru, 1979.

Sidharta, Bernard Arief. "Penelitian Hukum Normatif." In Metode Penelitian Hukum: Konstelasi Dan Refleksi, 142-149. Jakarta: Yayasan Obor Indonesia, 2009.

Stammler. Theorie Der Rechtwissenschaft. Halle: Buchhandlung des Waisenhauses, 1911.

Tamanaha, Brian Z. "A Concise Guide to The Rule of Law." In Relocating The Rule of Law, 5. Oxford: Hart Publishing, 2009.

Vlies, I.C.van der. Buku Pegangan Perancang Peraturan Perundang-Undangan (Handboek Wetgeving). Jakarta: Direktorat Jenderal Peraturan Perundang- Undangan, Departemen Hukum dan Hak Asasi Manusia, 2005. 